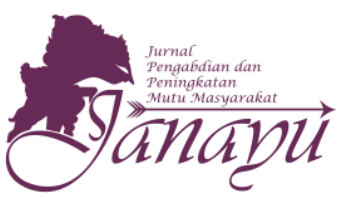

Website:

ejournal.umm.ac.id/index.php/janayu

Afiliasi:

${ }^{1}$ Universitas Bhakti Kencana,

Bandung, Jawa Barat, Indonesia

*Correspondence:

ratna.dian@bku.ac.id

DOI: $\underline{10.22219 / j a n a y u . v 1 i 2.11784}$

Sitasi:

Kurniawati, R.D., Kraar, M.H., Aulia, V.N, \& Kusaeri, M.T. (2020).

Peningkatan Akses Air Bersih Melalui Sosialisasi Dan Penyaringan Air Sederhana Desa Haurpugur. Jurnal Pengabdian dan Peningkatan Mutu Masyarakat, 1(2), 136- 143.

Proses Artikel

Diajukan:

3 April 2020

Direviu:

2 Juni 2020

Direvisi:

4 Juni 2020

Diterima:

8 Juni 2020

Diterbitkan:

29 Juli 2020

Alamat Kantor:

Jurusan Akuntansi Universitas

Muhammadiyah Malang

Gedung Kuliah Bersama 2

Lantai 3.

Jalan Raya Tlogomas 246,

Malang, Jawa Timur,

Indonesia

P-ISSN: 2721-0421

E-ISSN: 2721-0340
Tipe Artikel: Paper Pengabdian

\section{Peningkatan Akses Air Bersih Melalui Sosialisasi Dan Penyaringan Air Sederhana Desa Haurpugur}

Ratna Dian Kurniawati ${ }^{*}$, Mariana Henny Kraar ${ }^{1}$, Vivit Nurul Aulia ${ }^{1}$, M. Try Kusaeri ${ }^{1}$

\section{ABSTRACT}

The use of clean water is one of the tagsets of Clean and Healthy Life Behavior (PHBS) for Households. Data from the Central Statistics Agency (BPS) states that the achievement of access to safe water in Indonesia has only reached $72.55 \%$, below the Sustainable Development Goals (SDGs) target of 100\%. Water for Hygiene Purposes Sanitation is water of a certain quality that is used for daily needs whose quality is different from the quality of drinking water. Haurpugur villagers use water that does not meet health requirements. Water in Haurpugur village tends to contain iron. Some of the water sources are dug wells. Where dug wells with an average depth of wells range from 10-15 meters. At these depths, the Fe and Mn contents settle to the bottom of the well. Most (55.8\%) residents know well about the use of clean water. However, due to economic limitations, the fulfillment of clean water needs is ignored. In an effort to increase the knowledge of citizens and at the same time increase the coverage of clean water, it is necessary to carry out community service through socialization about clean water and making a simple filter of clean water. Achieving the fulfillment of clean water is a disease prevention limit that results from not fulfilling basic sanitation such as diarrhea.

KEYWORDS: Clean Water; Socialization; Simple Filter

\section{ABSTRAK}

Penggunaan air bersih merupakan salah satu taget Perilaku Hidup Bersih dan Sehat (PHBS) Rumah Tangga. Data Badan Pusat Statistik (BPS) menyebutkan capaian akses air bersih yang layak di Indonesia baru mencapai $72,55 \%$, di bawah target Sustainable Development Goals (SDGs) yakni sebesar 100\%. Air untuk Keperluan Higiene Sanitasi adalah air dengan kualitas tertentu yang digunakan untuk keperluan sehari-hari yang kualitasnya berbeda dengan kualitas air minum. Masyarakat desa Haurpugur memanfaatkan air yang tidak memenuhi syarat kesehatan. Air di desa Haurpugur cenderung mengandung besi. Sebagian sumber air adalah sumur gali. Dimana sumur gali dengan rata-rata kedalaman sumur berkisar 10 - 15 meter. Pada kedalaman tersebut kandungan Fe dan Mn banyak mengendap di dasar sumur. Sebagian besar $(55,8 \%)$ warga mengetahui dengan baik tentang penggunaan air bersih. Namum karena keterbatasan ekonomi maka pemenuhan akan kebutuhan air bersih diabaikan. Dalam upaya meningkatkan pengetahuan warga dan sekaligus meningkatkan cakupan air bersih maka perlu melaksanakan pengabdian masayrakat melalui sosialisasi tentang air bersih dan pembuatan saringan sederhana air bersih. Ketercapaian pemenuhan air bersih menjadi batas pencegahan penyakit yang bersumber pada tidak terpenuhinya sanitasi dasar seperti diare.

KATA KUNCI: Air Bersih; Sosialisasi; Saringan Sederhana 


\section{PENDAHULUAN}

Sesuai dengan hasil MMD dengan aparatur Desa, Tokoh Masyarakat dan masukan dari Puskesmas Nanjungmekar maka dalam pengabdian masyarakat ini akan difokuskan pada permasalahan peningkatan pengetahuan masyarakat RW 003 Desa Haurpugur dan juga memberdayakan masyarakat dalam penyediaan air bersih secara mandiri melalui penyaringan air sederhana.

Desa Haurpugur, Kecamatan Rancaekek menjadi salah satu wilayah yang sering dilanda banjir selama lima tahun terakhir ini di Kabupaten Bandung. Banjir di Desa Haurpugur, Kecamatan Rancaekek sering terjadi karena banjir besar tiba-tiba yang merendam rumah hingga jalan utama. Banjir yang terjadi Desa Haurpugur merupakan luapan Sungai Citarik yang kadang terjadi tanpa adanya hujan sekalipun. Apalagi jika musim penghujan datang sudah dipastikan debit air sungai Citarik akan meningkat dan berisiko terjadi banjir. Tinggi banjir bisa mencapai $150 \mathrm{~cm}$ merendam seluruh bagian rumah dan badan jalan. Di jalan utama Desa Haurpugur, yakni Jalan Haurpugur, setiap banjir sampah akan berserakan mengiringi air yang merendam pemukiman dan baru akan surut selama tiga hari.

Masyarakat di desa Haurpugur mempunyai akses yang mudah untuk memperoleh sumber air. Hampir seluruh penduduk memakai sumur permukaan atau sumur gali. Berdasarkan hasil Musyawarah Masyarakat Desa (MMD) dapat diketahui bahwa kualitas air yang kurang bagus menjadi salah satu permasalahan yang dihadapi oleh masyarakat Desa Haurpugur. Air yang didapatkan dari sumur permukaan cenderung keruh karena sering terpapar air luapan sungai Citarik dan air sumur juga mengandung Zat besi (Fe). Air yang ada berwarna kekuningan karena mengandung endapan zat besi dan mangaan. Warga cenderung abai dalam memanfaatkan air tersebut untuk pemenuhan kebutuhan sehari-hari. Untuk air minum warga membeli air dalam bentuk jerigen

Keamanan dan kualitas air sangat penting bagi perkembangan dan kesejahteraan manusia. Menyediakan akses ke air bersih adalah salah satu instrumen paling efektif dalam mempromosikan kesehatan dan mengurangi kemiskinan. Sebagai otoritas internasional tentang kesehatan masyarakat dan kualitas air, WHO memimpin upaya global untuk mencegah penularan penyakit yang ditularkan melalui air. Ini dicapai dengan mempromosikan peraturan berbasis kesehatan kepada pemerintah dan bekerja dengan mitra untuk mempromosikan praktik manajemen risiko yang efektif kepada pemasok air, masyarakat dan rumah tangga(WHO, 2020). WaterAid pada 2016 menyebutkan, lebih dari 40 persen penduduk di 16 negara tidak memiliki akses terhadap fasilitas air, bahkan sumur sekalipun. Komunitas yang terpinggirkan ini harus mengumpulkan air dari kolam dan sungai serta menghabiskan sebagian besar pendapatan harian mereka untuk membeli air bersih(Perpamsi, 2018). Sekitar 2 miliar orang minum air yang terkontaminasi secara feses, 4,5 miliar orang menggunakan sistem sanitasi yang tidak cukup melindungi keluarga(WHO, 2019).

Strategi WHO WASH telah dikembangkan sebagai tanggapan terhadap Resolusi Negara Anggota WHA 64.4 dan Agenda 2030 untuk Pembangunan Berkelanjutan dan Tujuan Pembangunan Berkelanjutan (SDGs). Juga diperlukan perlunya realisasi progresif hak asasi manusia atas air minum dan sanitasi yang aman, yang diadopsi oleh Majelis Umum PBB pada bulan Juli 2010. Tanggal akhir Strategi 2025 diusulkan untuk memungkinkan keduanya berwawasan ke depan yang dikelola dengan wajar. periode waktu serta waktu untuk mengadopsi strategi WHO baru pada tahun 2025 untuk memungkinkan koreksi kursus dalam periode lima tahun terakhir SDGs(WHO, 2018). 
Sasaran SDGs pada tahun 2030 adalah tercapainya akses universal dan merata terhadap air minum yang aman dan terjangkau bagi semua. Untuk Indonesia, target dan sasaran tersebut telah ditetapkan dalam RPJMN 2015-2019, melalui peningkatan akses terhadap layanan air minum layak pada tahun 2019 menjadi 100\%(Sekretariat Kabinet, 2017). Akses layanan air layak minum di Indonesia kini baru mencapai 72\%(Indonesia.Go.Id, 2019).

Penyediaan air untuk memenuhi kebutuhan masyarakat merupakan salah satu agenda penting dalam menjamin kebutuhan dasar masyarakat. Sayangnya, meskipun secara potensial ketersediaan air relatif melimpah, masih sering dijumpai masyarakat yang mengalami kesulitan dalam mengakses dan memenuhi kebutuhan air bagi kehidupan seharihari. Selain itu, masuknya pihak swasta untuk investasi pembangunan sistem penyediaan air minum merupakan ancaman serius bagi masyarakat untuk mengakses dan memanfaatkan sumber-sumber air bagi kebutuhan air minum.

Persyaratan kualitas air dalam Peraturan Menteri Kesehatan Republik Indonesia Nomor : 416/MENKES/PER/IX/1990 Tanggal : 3 September 1990 yang dipertegas dalam Peraturan Menteri Kesehatan Republik Indonesia Nomor 32 Tahun 2017 adalah 1mg/l. Standar Baku Mutu Kesehatan Lingkungan untuk media Air untuk Keperluan Higiene Sanitasi meliputi parameter fisik, biologi, dan kimia yang dapat berupa parameter wajib dan parameter tambahan. Parameter wajib merupakan parameter yang harus diperiksa secara berkala sesuai dengan ketentuan peraturan perundang-undangan, sedangkan parameter tambahan hanya diwajibkan untuk diperiksa jika kondisi geohidrologi mengindikasikan adanya potensi pencemaran berkaitan dengan parameter tambahan. Air untuk Keperluan Higiene Sanitasi tersebut digunakan untuk pemeliharaan kebersihan perorangan seperti mandi dan sikat gigi, serta untuk keperluan cuci bahan pangan, peralatan makan, dan pakaian. Selain itu Air untuk Keperluan Higiene Sanitasi dapat digunakan sebagai air baku air minum(Kemenkes, 2017). Dimana dijelaskan bahwa juga mengenai air bersih adalah air yang digunakan untuk keperluan sehari-hari yang kualitasnya memenuhi syarat kesehatan dan dapat diminum apabila telah dimasak(Kemenkes, 1990).

Air mengandung besi tinggi bisa berbahaya. Zat besi $(\mathrm{Fe})$ adalah zat yang sangat berbahaya bagi tubuh manusia dan sudah tentu tak boleh sampai masuk ke dalam tubuh. Tingginya kadar besi dalam air tak hanya mengganggu berbagai pekerjaan sehari-hari tetapi juga dapat mengganggu kesehatan tubuh pemakainya. Pemerintah telah mengatur standar kandungan zat besi pada air melalui Permenkes RI No. 416/Menkes/Per/IX/1990. Di dalam Permenkes tersebut dijelaskan air mengandung besi boleh dikonsumsi asalkan kadar maksimal zat besinya kurang dari 1,0 mg per liter. Air mengandung besi tinggi banyak terdapat pada air sumur bor, terutama sumur bor yang digali dengan kedalaman yang rendah. Air tersebut terasa licin, menimbulkan kerak pada pakaian, tidak nyaman saat dipakai mandi, air jernih ketika ditampung, tetapi berubah warna kuning saat diendapkan, berbau tajam, kombinasi bau besi dan bau tanah.

Bahaya air mengandung zat besi adalah endapan Fe yang bersifat korosif, apabila kandungan zat besi dalam air melebihi $10 \mathrm{mg}$ per liter, hal itu akan mengubah warna, aroma dan rasa air pada tubuh Anda, pasokan zat besi berlebih akan menimbulkan masalah kesehatan. Bahaya paparan zat besi dalam jumlah banyak dan dalam waktu lama bisa mengganggu organ pencernaan, kulit, hingga otak.

Komarulzaman menyatakan kaitan antara akses air bersih pada rumah tangga dengan kebiasaan ibu rumah tangga untuk memasak air sebelum diminum. Ketersediaan akses air bersih dan kebiasaan memasak air sebelum diminum diharapkan dapat menurunkan peluang munculnya wabah diare dan diare akut di sebuah desa dan kecamatan, dengan

Janayu 1.2 
menggunakan data Survey Demograsi tahun 2007 dan 2012. Kairulzaman menyimpulkan bahwa akses air yang dialirkan dengan pipa atau ledeng, kondisi sanitasi lingkungan yang baik, dan pendapatan keluarga berpengaruh negatif terhadap insiden diare. Peningkatan akses air bersih dan sanitasi ditemukan berpengaruh positif terhadap peningkatan nilai PDRB wilayah kabupaten/kota di Indonesia peningkatan akses air bersih yang ditemukan berpengaruh pada penurunan tingkat morbiditas penduduk(Sukartini, 2016). Studi yang dilakukan oleh Febriany berfokus pada pengaruh akses air bersih dan peningkatan sanitasi lingkungan terhadap angka kematian bayi usia di bawah lima tahun dan pelambatan pertumbuhan fisik (stunting). Studi ini menggunakan data Survei Sosial dan Ekonomi Nasional (Susenas) 2009 dan 2010. Secara umum, analisis dalam studi ini menemukan bahwa ada korelasi negatif dari peningkatan akses air bersih dan perbaikan sanitasi lingkungan terhadap angka kematian bayi di bawah usia lima tahun dan pelambatan pertumbuhan fisik(Sukartini, 2016).

Penyediaan air bersih bagi masyarakat, tidak hanya merupakan tanggung jawab pemerintah dan pemerintah daerah. Tetapi juga merupakan tanggung jawab bersama, yaitu Pemerintah (pusat maupun daerah), Swasta, dan masyarakat. Masing-masing menjalankan peran sesuai kapasitas, dengan didasari kesadaran bahwa ketersediaan air bersih memerlukan kesadaran bersama untuk menjaga sumber-sumber air yang ada agar tetap lestari dan tidak berlaku boros dalam menggunakan air bersih yang ada(Prihatin, 2015).

Kepentingan terhadap perilaku memakai air bersih menjadi dasar pertimbangan seseorang untuk berniat melakukan sesuatu. Jika ia menganggap apa yang akan dilakukannya penting maka pada tahap selanjutnya ia yang didukung oleh sikap, norma yang dipersepsikan dan kondisi personalnya. Niat dan hambatan lingkungan berpengaruh terhadap perilaku mempergunakan air bersih di tatanan rumah tangga (Raksanagara, 2017).

Ketersediaan air di suatu wilayah utamanya dipengaruhi oleh tiga komponen, yaitu: (i) adanya sumber daya air yang memadai; (ii) adanya kebijakan dan kelembagaan yang memadai untuk melakukan pengelolaan sumber daya air; dan (iii) adanya infrastruktur untuk penyediaan air(Alihar, 2018). Di RW 003 Desa Haurpugur sebagian warganya memanfaatkan Sumur Gali. Walaupun kondisi air yang ada kualitasnya tidak memenuhi syarat. Air yang ada berwarna kekuningan karena mengandung endapan zat besi dan mangaan. Warga cenderung abai dalam memanfaatkan air tersebut untuk pemenuhan kebutuhan sehari-hari. Untuk air minum warga membeli air dalam bentuk jerigen.

Maka dalam pengabdian masyarakat ini akan difokuskan pada permasalahan peningkatan pengetahuan masyarakat RW 003 Desa Haurpugur. Dan memberdayakan masyarakat dalam penyediaan air bersih secara mandiri melalui penyaringan air sederhana.

\section{METODE}

Metode pengabdian masyarakat difokuskan dalam peningkatan pengetahuan masyarakat RW 003 Desa Haurpugur dilakukan melalui penyuluhan dengan media power point. Dan memberdayakan masyarakat dalam penyediaan air bersih secara mandiri melalui demontrasi pembuatan saringan sederhana untuk menyaring air di rumah masing-masing. Peningkatan pengetahuan masyarakat RW 003 Desa Haurpugur dilakukan melalui sosialisasi dan penyuluhan guna memberikan dan meningkatkan informasi mengenai Pentingnya Air Bersih dan Manfaatnya Bagi Kesehatan. Sedangkan pemberdayaaan masyarakat dalam

1.2 penyediaan air bersih secara mandiri melalui penyaringan air sederhana ditujukan supaya setiap warga masyarakat mampu secara mandiri melakukan treatment sederhana untuk meningkatkan kualitas air yang dipakai sehari hari mengingat pada dasarnya masyarakat 
mudah memperoleh akses air akan tetapi kualitas air yang tidak memenuhi syarat. Dengan harapan akses air bersih mudah bisa menjadikan masyarakat sehat.

Kesehatan seseorang atau masyarakat dipengaruhi oleh faktor-faktor, yakni faktor perilaku dan faktor diluar perilaku. Menurut Lawrence Green bahwa perilaku manusia terbentuk dari faktor predisposisi yang terwujud dalam pengetahuan, sikap, kepercayaan keyakinan dan nilai-nilai, faktor pendukung yang terwujud dalam lingkungan fisik, tersedia atau tidak bersedianya fasilitas-fasilitas atau sarana-sarana kesehatan dan faktor pendorong yang terwujud dalam sikap dan perilaku petugas kesehatan atau petugas lainnya yang merupakan kelompok retefensi dari perilaku masyarakat. Merubah perilaku seseorang memerlukan strategi, yaitu melalui penggunaan kekuasaan/kekuatan, pemberian informasi dan diskusi partisipasi(Notoatmodjo, 2014).

Perubahan perilaku penggunaan air bersih harus diawali dulu dengan memberikan stimulus pengetahuan yang baik mengenai pentingnya air bersih yang penting bagi kesehatan masyarakat. Memberikan informasi-informasi penyuluhan dan cara filtrasi air sederhana akan meningkatkan pengetahuan masyarakat tentang pemenuhan air bersih untuk kehidupan sehari-hari. Memberi intervensi kepada masyarakat melalui penyuluhan dengan teknik KIE (Komunikasi, Informasi, dan Edukasi) dengan tujuan meningkatkan kesadaran akan pentingnya penggunaan air bersih.

Adapun langkah-langkah yang dilakukan pada saat melakukan intervensi pada masyarakat diawali dengan perkenalan diri, menjelaskan tentang maksud dan tujuan penyuluhan, memaparkan materi tentang pentingnya air bersih, demonstrasi dan memberdayakan masyarakat dalam pembuatan saringan air sederhana, pemasangan alat penyaringan sederhana di posyandu, diskusi tanya jawab, dokumentasi dan penutupan.

Pada pelaksanaan intervensi ini melibatkan ibu-ibu kader yang ada di masyarakat. Dengan tujuan adalah mengingat peran kader sebagai agent of change. Diharapkan kader dapat berperan serta lebih maksimal. Sehingga terjadi perubahan yang signifikan dengan adanya peran serta aktif dari kader yang merupakan bagian dari masyarakat itu sendiri. Pemberdayaan Masyarakat Bidang Kesehatan, yang selanjutnya disebut Pemberdayaan Masyarakat adalah proses untuk meningkatkan pengetahuan, kesadaran dan kemampuan individu, keluarga serta masyarakat untuk berperan aktif dalam upaya kesehatan yang dilaksanakan dengan cara fasilitasi proses pemecahan masalah melalui pendekatan edukatif dan partisipatif serta memperhatikan kebutuhan potensi dan sosial budaya setempat(Kemenkes, 2019)

\section{HASIL DAN PEMBAHASAN}

Data yang terlihat di atas adalah hasil dari pre test dan post test. Berdasarkan grafik di atas masyarakat kurang memahami tentang pentingnya air bersih. Dan dari grafik juga dapat dilihat bahwa terjadi peningkatan pengetahuan masyarakat sesudah mengikuti penyuluhan yaitu mengalami perubahan. Terjadi peningkatan jumlah masyarakat yang berpengetahuan baik. Hal ini merupakan hasil dari informasi-informasi melalui penyuluhan yang meningkatkan pengetahuan masyarakat tentang pentingnya air bersih. Selanjutnya pengetahuan-pengetahuan tersebut akan menimbulkan kesadaran masyarakat dan akhirnya akan menyebabkan masyarakat berperilaku sesuai dengan pengetahuan yang dimilikinya(Notoatmodjo, 2014). Masyarakat akan selalu berusaha memenuhi kebutuhan akan air bersih sebagai upaya pencegahan dari penyakit yang bersumber dari air. Perilaku

Janayu 1.2 kesehatan seseorang atau masyarakat ditentukan oleh niat orang terhadap objek kesehatan, ada atau tidaknya dukungan dari masyarakat sekitarnya, ada atau tidaknya informasi tentang 
kesehatan, kebebasan dari individu untuk mengambil keputusan/bertindak, dan situasi yang memungkinkan ia berperilaku/bertindak atau tidak berperilaku/tidak bertindak(Notoatmodjo, 2014)

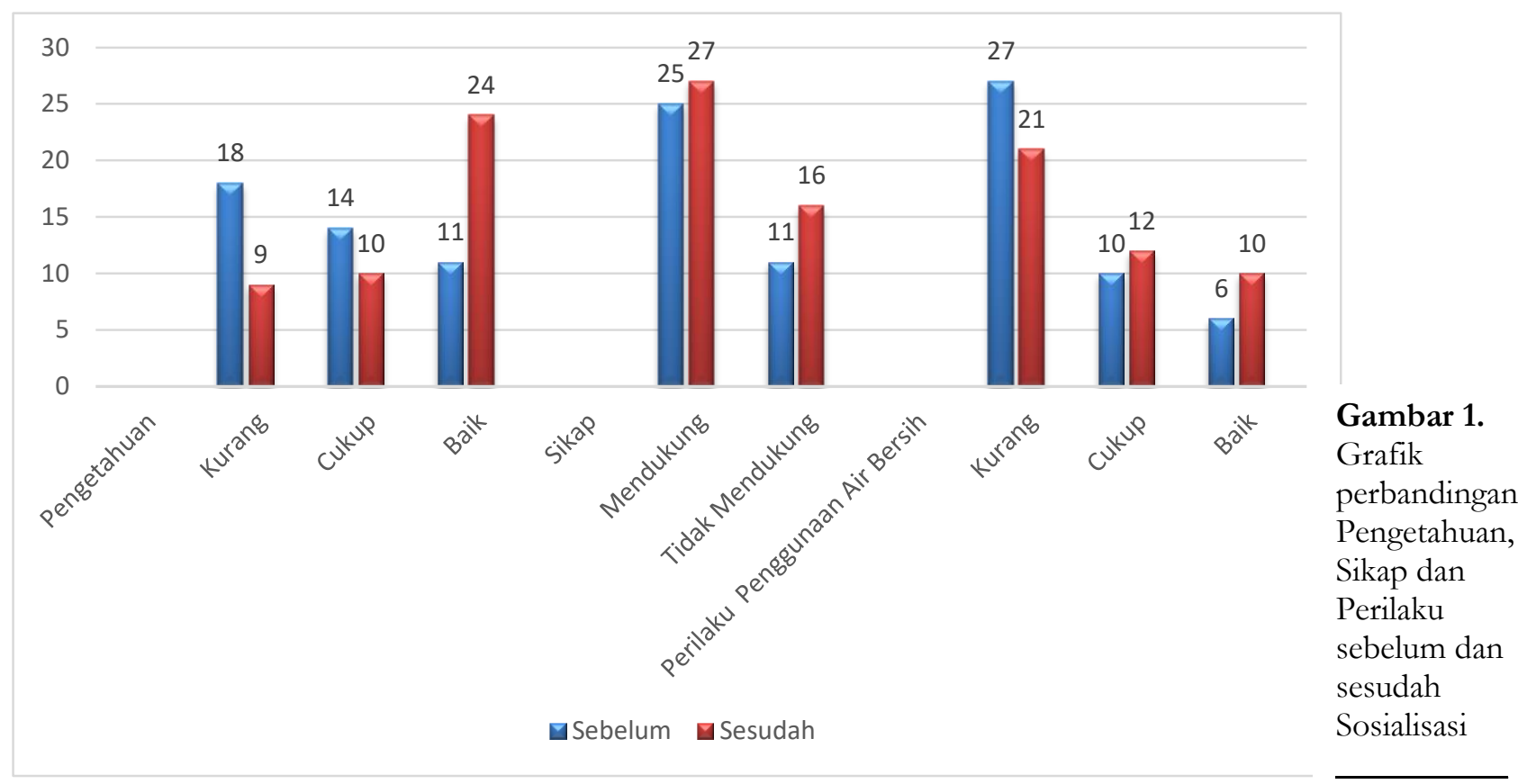

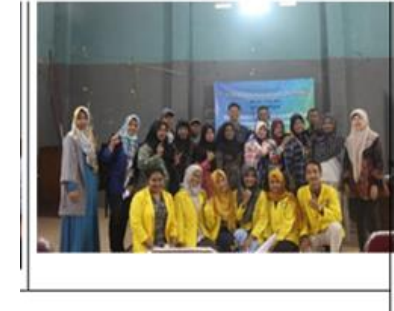
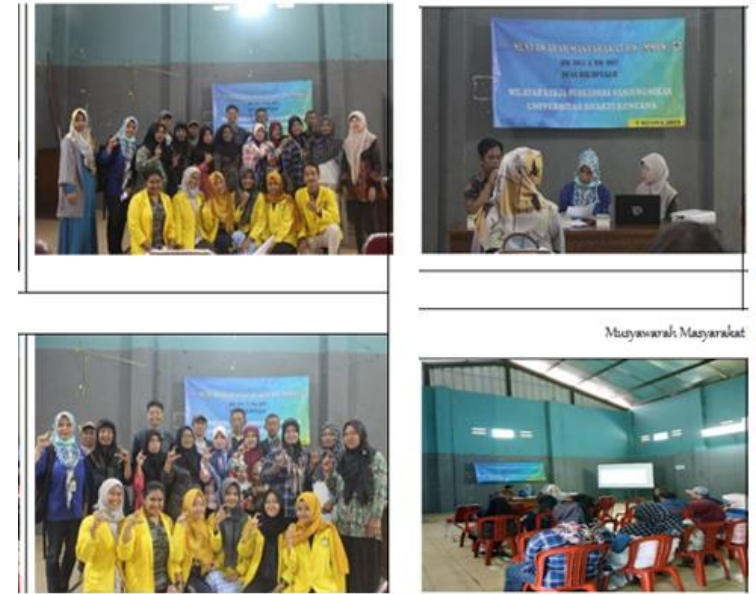
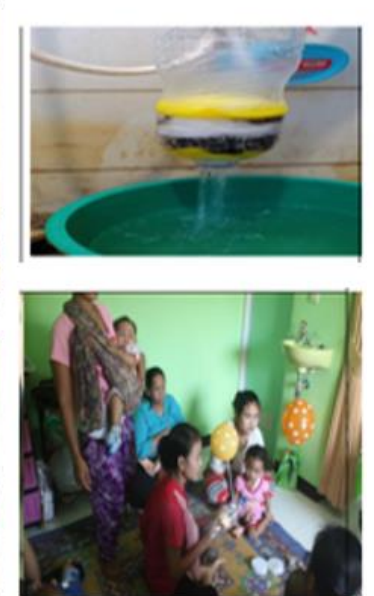

Gambar 2.

Dokumentasi

Pengabdian

Masyarakat

Desa

Haurpugur

2019

Penyuluhan berjalan dengan lancar dan sesuai dengan yang diharapkan. Peserta penyuluhan berjumlah 43 orang. Dengan adanya perwakilan dari RW, kader, perwakilan warga dari setiap RT, dan Bidan Desa.

Masyarakat RW 003 yang mengikuti penyuluhan menjadi lebih mengetahui syarat air bersih yang dapat digunakan untuk aktivitas sehari-hari. Dimana syarat air bersih yang digunakan masyarakat harus memenuhi persyaratan yang tertera dalam Peraturan Menteri Kesehatan Republik Indonesia Nomor 32 Tahun 2017 adalah 1mg/l. Standar Baku Mutu

1.2 Kesehatan Lingkungan untuk media Air untuk Keperluan Higiene Sanitasi meliputi parameter fisik, biologi, dan kimia yang dapat berupa parameter wajib dan parameter tambahan. 
Saat berlangsungnya kegiatan penyuluhan masyarakat sangat aktif khususnya pada bagian tanya jawab dan demonstrasi mengenai pemeliharaan sarana air bersih. Memberikan informasi tentang kesehatan tidak searah tetapi dua arah. Hal ini menempatkan masyarakat tidak hanya pasif menerima informasi, tetapi masyarakat menjadi aktif berpartisipasi melalui diskusi-diskusi tentang informasi yang diterimanya. Diskusi partisipasi adalah salah satu cara yang baik dalam rangka memberikan informasi dan pesan-pesan kesehatan(Notoatmodjo, 2014). Selain diskusi mengenai pentingnya air bersih untuk pemenuhan kebutuhan sehari-hari. Dilaksanakan juga demontrasi pembuatan saringan sederhana yang bisa menyaring zat besi yang terkandung dalam air. Sehingga air yang diperoleh hasil dari penyaringan sederhana relative lebih jernih dan berkurang kandungan endapan zat besinya. Hasil dari pembuatan saringan sederhana kemudian dipasang di kamar mandi Posyandu di RW 003.

\section{SIMPULAN}

Pengabdian masyarakat yang telah selesai dilaksanakan mempunyai dampak dapat meningkatkan pengetahuan masyarakat tentang pentingnya air bersih. Dan masyarakat mampu menyediakan air bersihnya dengan membuat saringan sederhana untuk mendapatkan air bersih secara mandiri. Perlunya kerjasama lintas sektoral Puskesmas dengan pemerintah Desa Haurpugur untuk swasembada penyediaan air bersih secara terintegrasi sehingga manfaatnya lebih luas ke seluruh desa. Mengingat air bersih merupakan hak dan kebutuhan seluruh warga desa.

\section{DAFTAR PUSTAKA}

Alihar, F. (2018) 'Penduduk Dan Akses Air Bersih Di Kota Semarang (Population And Access To Clean Water In Semarang City)', Jurnal Kependudukan Indonesia, Vol. 13 No(Juni 2018), pp. 67-76.

Indonesia.Go.Id (2019) Air Bersih: Mengejar Pencapaian Akses 100\% di 2019, bttps://indonesia.go.id/ narasi/indonesia-dalam-angka/ ekonomi/ mengejar-pencapaian-akses-

100-di-2019. Available at: https://indonesia.go.id/narasi/indonesia-dalamangka/ekonomi/mengejar-pencapaian-akses-100-di-2019.

Kemenkes, R. (1990) Daftar Persyaratan Kualitas Air. Peraturan Menteri Kesehatan Republik Indonesia. Nomor : 416/MENKES/PER/IX/1990 Tanggal : 3 September 1990.

Kemenkes, R. (2017) Peraturan Menteri Kesehatan Republik Indonesia Nomor 32 Tabun 2017 Tentang Standar Baku Mutu Kesehatan Lingkungan Dan Persyaratan Kesehatan Air Untuk.

Kemenkes, R. (2019) Peraturan Menteri Kesehatan Republik Indonesia Nomor 8 Tabun 2019 Tentang Pemberdayaan Masyarakat Bidang Kesehatan.

Notoatmodjo, S. (2014) Ilmu Perilaku Kesehatan. Jakarta: Rineka Cipta.

Perpamsi (2018) Selamat Hari Air Dunia 2018. Available at: https://perpamsi.or.id/berita/view/2018/03/22/468/selamat-hari-air-dunia-2018.

Prihatin, R. B. dkk (2015) Penyediaan Air Bersih Di Indonesia: Peran Pemerintah, Pemerintah Daerah, Swasta, Dan Masyarakat. Edited by S. N. Qodriyatun. Jakarta: P3DI Setjen DPR RI dan Azza Grafika. Available at: http://berkas.dpr.go.id/puslit/files/buku_tim/buku-tim-public-42.pdf.

Raksanagara, A. S. (2017) 'Faktor yang Memengaruhi Perilaku Penggunaan Air Bersih pada

Janayu 1.2 Masyarakat Kumuh Perkotaan', MKB, 49 NO: 2(Juni 2017). 
Sekretariat Kabinet, R. (2017) Lampiran Peraturan Presiden Republik Indonesia Nomor 59 Tabun 2017 tentang Pelaksanaan Pencapaian Tujuan Pembangunan Berkelanjutan. Available at: http://setkab.go.id/category/peraturan.

Sukartini, N. M. (2016) 'Akses Air Bersih di Indonesia', JURNAL EKONOMI KUANTITATIF TERAPAN, Vol. 9 No.(AGUSTUS 2016).

WHO (2018) WHO: Watern Sanitation and Higiene 2018-2025. Switzerland.

WHO (2019) WHO Global Water, Sanitation And Hygiene: annual Report 2018. Available at: https://apps.who.int/iris/bitstream/handle/10665/327118/WHO-CED-PHEWSH-19.147-eng.pdf?ua=1.

WHO (2020) Water safety and quality. Available at: https://www.who.int/water_sanitation_health/water-quality/en/. 